\title{
Evaluation of Cisplatin Efficacy on HepG2 and E. coli Cells under Acidic Conditions
}

\author{
Faezeh Babaei ${ }^{1}$, Hasan Ebrahimi Shahmabadi², Mohammad Reza Rajabi ${ }^{3}$, \\ Hamed Haddad Kashani ${ }^{1}$, Fatemeh Izadpanah ${ }^{4 *}$
}

\begin{abstract}
Background: Cisplatin (Cispt) is a common anticancer drug for the treatment of several malignancies, including hepatocarcinoma. However, this drug suffers from instability|in aqueous solutions. The study aimed to evaluate cisplatin efficacy on HepG2 and E. coli cells under an acidic condition. Methods: Acidic Cispt was prepared via incubation in acidic condition $(\mathrm{pH}=2)$ for a month duration. The chemical structure of the acidic Cispt was evaluated by using Fourier Transform Infrared Spectroscopy (FTIR) method. The cytotoxicity of the standard and acidic Cispt were then determined by 3-(4,5-dimethylthiazol-2-yl)-2,5-diphenyltetrazolium bromide (MTT) and minimum inhibitory concentration (MIC) assays on HepG2 and E. coli cells, respectively. Results: After preparing of acidic Cispt, its chemical structure was determined by FTIR method. In addition, cytotoxicity effects of Cispt in the standard and acidic forms were calculated $58 \pm 2.9$ and $65 \pm 3.25 \mu \mathrm{M}$, respectively. MIC results also confirmed the results of MTT assay. MIC results for the standard and acidic Cispt were estimated $9.5 \pm 0.47$ and $9.8 \pm 0.49 \mu \mathrm{M}$, respectively. Conclusion: Preparing Cispt in acidic condition not only did not degrade the drug, but also kept the potency of the drug approximately equal to parent drug. Regarding the instability issues of Cispt, keeping Cispt in acidic condition could be a promising approach to preserve its efficacy.
\end{abstract}

Keywords: Acidic cisplatin- HepG2- MIC assay- MTT assay- standard cisplatin

Asian Pac J Cancer Prev, 20 (3), 723-726

\section{Introduction}

Cisplatin (cis-diammine-dichloroplatinum) (Cispt) is one of the inorganic platinum-based chemotherapeutic and most widely used for the treatment of various types of cancers, including head and neck, prostate gland, liver, breast, cervix, uterus cancer and hepatocarcinoma, because this drug prevents cancer cells from dividing further (Panesso et al., 2014; Song et al., 2014; Singh et al., 2015). The discovery of Cispt was a breakthrough that triggered the interest in metal-containing compounds as potential anticancer drugs (Florea and Büsselber, 2011). However, various side effects, such as nephrotoxicity, nausea and vomiting, myelosuppression, immunosuppression and neurotoxicity, have been observed with Cispt therapy that cause its clinical use to be limited (Panesso et al., 2014; Shah and Dizon, 2009; Tsang et al., 2009). Although Cispt is one of the most commonly used anticancer agent (Lee et al. 2015), it is unstable in aqueous solutions (Sewell, 2010). The main form of this drug decomposition is displacement of the chloride ligand (Cubells et al., 1993). Cispt is frequently prepared in sodium chloride infusion. To prevent potential precipitation, the drug keeps at room temperature. In addition, chemical stability of the drug depends upon $\mathrm{pH}$ and sunlight. The preferable $\mathrm{pH}$ for maintaining the chemical structure of Cispt ranges between 3.5 and 5.5. Furthermore, the drug is somewhat sensitive to light (Sewell, 2010).

Escherichia coli (E. coli) is the type species of the genus Escherichia. The bacteria contain mostly motile gram-negative bacilli that fall within the family Enterobacteriaceae (Haddad Kashani et al., 2017; Stenutz et al., 2006). Also, E. coli is facultatively anaerobic, rod-shaped bacterium is commonly found in lower intestine of warm-blooded organisms (endotherms) (Singleton, 2004). E. coli is an important cause of urinary tract infections, enteric infections and systemic infections, such as bacteremia, nosocomial pneumonia, cholecystitis, cholangitis, peritonitis, cellulitis, osteomyelitis and infectious arthritis in humans (Jalali et al., 2016; Kashani and Moniri 2015; Mandell, 2000; Pitout, 2012). It is also leading cause of neonatal meningitis (Kashani et al., 2018; Pitout, 2012).

${ }^{1}$ Anatomical Sciences Research Center, Kashan University of Medical Sciences, Kashan, ${ }^{2}$ Department of Microbiology, Faculty of Medicine, Rafsanjan University of Medical Sciences, Rafsanjan, ${ }^{3}$ Faculty of Medicine, Shahed University of Medical Sciences, ${ }^{4}$ Food and Drug Laboratory Research Center and Food and Drug Reference Control Laboratories Center, Food and Drug Administration of Iran, MOH and ME, Tehran, Iran.*For Correspondence: fatemehizadpanah123@gmail.com 
This study aimed to evaluate cisplatin efficacy on HepG2 and E. coli cells under an acidic condition.

\section{Materials and Methods}

\section{Cell lines and chemical agents}

3-(4,5-dimethylthiazol-2-yl)-2,5-diphenyl-2Htetrazolium bromide (MTT) $(0.5 \mathrm{mg} / \mathrm{mL})$ and Cispt were obtained from Sigma Company (Sigma, USA). Dulbecco's modified Eagle's medium (DMEM) was purchased from Invitrogen (USA). Isopropanol and Hydrogen chloride ( $\mathrm{HCl})$ were obtained from Merck (Germany) and Zhechem (China), respectively. All other materials were of analytical grade. De-ionized water was used all through the study. HepG2 cell line and E. coli strain were supplied by Pasteur Institute of Iran, Tehran.

\section{Preparation of acidic Cispt}

To prepare acidic Cispt, $2 \mathrm{mg}$ of Cispt in powder form (standard Cispt) was dissolved in $1 \mathrm{~mL} \mathrm{HCl} 0.01 \mathrm{~N}$. After one month, solvent phase was evaporated and Acidic Cispt in was obtained again.

\section{Evaluating the acidic Cispt by using FTIR method}

For this purpose, the acidic Cispt was dried in room temperature, mixed with bromide potassium and then pressed to prepare the tablet. Next, the tablet was analyzed by FTIR (Nicolet 740SX FTIR spectrophotometer with an MCT-B detector (USA)).

\section{Determination of MIC}

MIC is the lowest concentration of an antimicrobial agent capable to halt the growth of a microorganism (Kashani et al., 2012; Hosseini et al., 2016). For this purpose, $100 \mu \mathrm{L}$ Luria Broth bacteria culture medium was introduced in 96-well plates. Acidic Cispt, standard Cispt and bacterial suspension were then added. Next, the plate was incubated at $37^{\circ} \mathrm{C}$ for $24 \mathrm{~h}$. The bacterial growth was determined as absorbance raise by Elisa reader (Bio Tek Instruments, VT, USA) at $600 \mathrm{~nm}$. The experiment repeated three times (Panghal et al., 2011; Ferdosian et al. 2015).
In vitro cytotoxicity of the Cispt

The cytotoxicity of the standard and acidic Cispt was determined by MTT assay in HepG2 cell line on 96-well plates. Cells were seeded in dilution rate of $1 \times 104$ for each well in DMEM containing 10\% Fetal Bovine Serum (FBS), $2 \mathrm{mM}$ glutamine, and antibiotics (60 mg/L penicillin $\mathrm{G}, 100 \mathrm{mg} / \mathrm{L}$ streptomycin, $50 \mu \mathrm{L} / \mathrm{L}$ amphotericin B) $\left(37^{\circ} \mathrm{C}, 5 \% \mathrm{CO}_{2}\right)$. They were allowed to attach for $48 \mathrm{~h}$. The culture media were then removed and cells were treated with the standard and acidic Cispt at the concentrations of $160,80,40,20$ and $0 \mu \mathrm{M}$. After $24 \mathrm{~h}$ incubation, the drug containing culture was removed and $100 \mu \mathrm{L}$ MTT solutions $(0.5 \mathrm{mg} / \mathrm{mL}, \mathrm{pH} 7.4)$ was added to each well and incubated for $3 \mathrm{~h}$ at $37^{\circ} \mathrm{C}$. Later, MTT was discarded and $100 \mu \mathrm{L}$ isopropanol $100 \%$ was added to dissolve the formazan crystals. Next, absorbance was read at $540 \mathrm{~nm}$ using spectrophotometric method. Finally, IC50 was measured by statistical package Pharm-PCS software, and cell viability (V) was calculated as in Eq. 1 (Sanganeria et al., 2015).

Cell viability $(\%)=$ sample absorbance/control absorbance $\times 100$

\section{Statistical analysis}

The results of MIC assay were analyzed by using Excel program and are expressed as mean with standard deviation. In addition, the results of MTT assay were analyzed by one-way ANOVA and T-test and the significance level was set at $\mathrm{p}<0.05$ (Lotfi et al. 2016; Piroozmand et al. 2017). For this purpose, SPSS version 19.00 software (SPSS, Chicago, IL, USA) was used.

\section{Results}

\section{Preparation of acidic Cispt}

Cispt powder was effortlessly derived from the acidic solution. From the morphological point of view, Cispt kept the color and solidity as parent compound. The difference results between standard and acidic Cispt in MTT assay was not statistically significant $(\mathrm{p}=0.15)$.

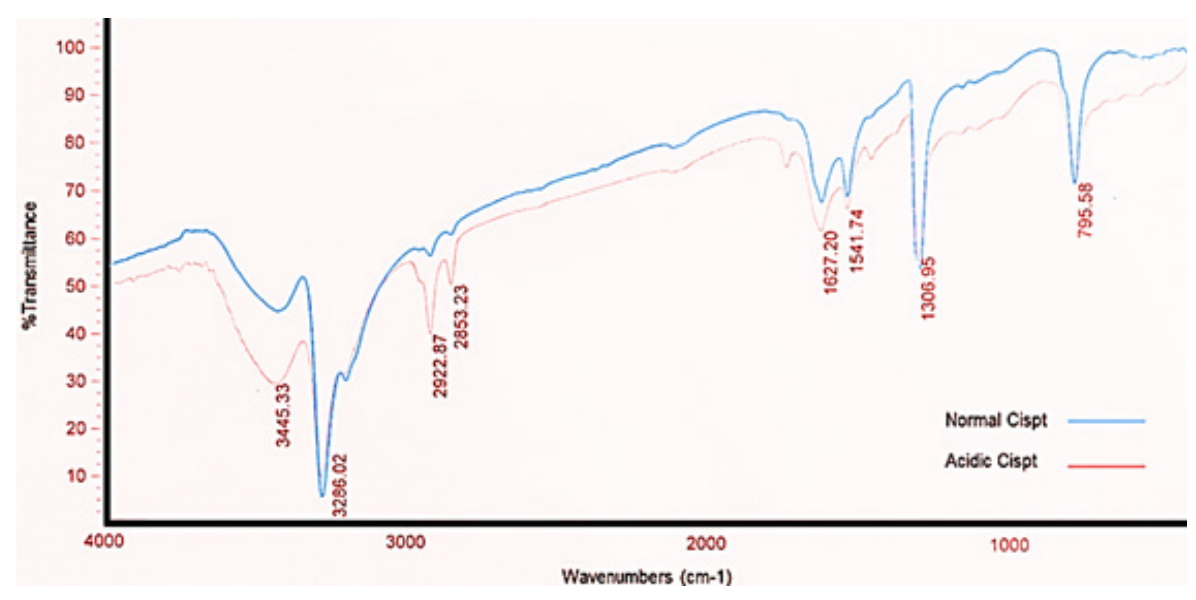

Figure 1. FTIR Spectrum of Acidic Cispt. The figure shows the Cispt-related peaks which kept in acidic condition. The results showed that the acidic Cispt preserved its chemical structure. Also, chemical bonds of acidic Cispt were approximately equal to those of standard Cispt. 


\section{Evaluating the acidic Cispt by using FTIR}

FTIR results showed Cispt preserved its chemical structure (Figure 1). Platinum and ammonium bond was appeared in $463 \mathrm{~cm}^{-1}$ while platinum and chloride was appeared in $338 \mathrm{~cm}$ and $362 \mathrm{~cm}^{-1}$. In addition, tensional trembles of ammonium groups emerged in $1,550 \mathrm{~cm}^{-1}$, $1,680 \mathrm{~cm}^{-1}, 3,300 \mathrm{~cm}^{-1}$, and $3,500 \mathrm{~cm}^{-1}$ (Shahmabadi et al., 2014). As Figure 1 indicated, chemical bonds of Cispt were preserved and did not changed in acidic Cispt.

\section{Determination of MIC}

The lowest concentration inhibitory of the standard and acidic Cispt was evaluated through MIC assay on E. coli strain. The results for the standard and acidic Cispt were measured $9.5 \pm 0.47$ and $9.8 \pm 0.49 \mu \mathrm{M}$, respectively $(\mathrm{p}=0.59)$

\section{In vitro cytotoxicity of the drug}

The cell viability of the standard and acidic Cispt on the HepG 2 cell line after $24 \mathrm{~h}$ incubation and cytotoxicity of the various concentrations of Cispt was investigated via MTT assay on HepG2 cell lines. IC50 of the standard and acidic Cispt were estimated at $58 \pm 2.9$ and $65 \pm 3.25$ $\mu \mathrm{M}$, respectively $(\mathrm{p}=0.15)$.

\section{Discussion}

Cispt in water solution that is free of $\mathrm{Cl}^{-}$ions becomes quickly decomposed, because of substitution reaction between one or both the chlorine atoms of the drug and water molecule. This consequently results in reduction of the drug concentration by $30-35 \%$ just after 4 hours (Allwood et al., 2002). Zieske et al., (1991) study confirmed that Cispt degradation depended upon $\mathrm{pH}$ values. The results showed that nearly $0.04 \%$ and $0.21 \%$ of the drug was decomposed per week at $\mathrm{pH} 4.3$ and 6.3 , respectively. In their study, high-performance liquid chromatography technique along with $\mathrm{pH}$ measurement were used to determine the stability of Cispt (Zieske et al., 1991). In another study, Hrubigkol et al. evaluated the stability of Cispt solutions in the concentrations of 1.0 and $1.6 \mathrm{mg} / \mathrm{ml}$ deposited in plastic infusion bags for two weeks. They found that temperature had no effect on the rate of the drug degradation. However, they observed that $\mathrm{Cispt}$ concentration was proportional with the solution temperature $\left(25^{\circ} \mathrm{C}<1 \%, 37^{\circ} \mathrm{C}<3 \%, 60^{\circ} \mathrm{C}-8.2 \%\right)$ (Hrubiško et al., 1992). In contrast, Mitter et al. study demonstrated that temperature has the significant effect on the Cispt stability (Mittner et al., 1998). In this study, Cispt in the concentration of $0.1 \mathrm{mg} / \mathrm{ml}$ was prepared and kept in room temperature and refrigerator for 7 days. The drug loss rate kept in room temperature was significantly higher than the drug stored in refrigerator $(84.5 \pm 1.5 \%$ in room temperature compared to $97.4 \pm 0.9 \%$ in refrigerator) (Mittner et al., 1998).

Also, It has been demonstrated that the drug did not interact with the packages, infusion bags or other elements used for preparing the final product of Cispt (Cubells et al., 1993). Cubells et al., (1993) evaluated a solution of the drug with the concentration of $0.166 \mathrm{mg} / \mathrm{ml}$, protected it from the light, and stored at room temperature $\left(30^{\circ} \mathrm{C}\right)$.
Results of the study indicated the stability of the drug for 14 days in all storage containers: polypropylene bags (100.1 $\pm 0.5 \%)$, glass bottles $(99.7 \pm 0.3 \%)$, polyethylene bags $(98.9 \pm 1.0 \%)$ and PVC bags $(104.6 \pm 1.0 \%)$.

Rochard et al., (1992) prepared the concentration of 0.5 and $0.9 \mathrm{mg} / \mathrm{ml}$ of Cispt and located into ambulatory infusion pumps constructed from ethylene-vinyl acetate at $22^{\circ} \mathrm{C}$ and $35^{\circ} \mathrm{C}$ for 28 days. The results of the study confirmed the stability of Cispt in the both concentrations.

In the present study, we prepared Cispt in acidic solution at $\mathrm{pH} 2$. Acidic Cispt was provided in the concentration of $2 \mathrm{mg} / \mathrm{mL}$ without difficulty. Cispt in acidic solution kept the appearance perfectly. FTIR results also confirmed that the chemical structure of Cispt was remained intact. The efficacy of Cispt was evaluated with MTT and MIC assays. Cytotoxicity results confirmed Cispt kept the efficacy under acidic conditions after one month. MIC results also demonstrated acidic Cispt has potency as compare as parent compound. This study is highlighted with the simplicity of evaluation methods for examine the drug efficacy which is reported for first time. Comparison the efficacy of acidic solution derived Cispt with the typical form of Cispt in sodium chloride infusion could be suggested as future work. Finally, the results of the study indicated that acidic conditions at $\mathrm{pH}$ 2 not only did not have detrimental effects on the stability of Cispt but also kept its efficacy approximately compared to parent Cispt.

In conclusion, Cispt is one of the frequently used anticancer drug for various malignancies. However, Cispt instability has considered as a drawback for the clinical use. Enhancing the stability of Cispt could improve the efficacy of the drug. So, as a solution, in this research, Cispt was incubated in acidic conditions. MTT and MIC techniques were used to evaluate the cytotoxicity and bactericidal effects of Cispt, respectively. FTIR method was used to determine the chemical structure of the drug as well. The study showed that keeping Cispt in acidic condition could be regarded for preserving the Cispt potency against degradation and moreover keeping the functionality of the drug for therapeutic purposes.

\section{Compliance with Ethical Standards}

This article does not contain any studies with human participants or animals performed by any of the authors.

\section{Conflict of interest \\ None declared.}

\section{Acknowledgments}

The study was performed as a part of M.Sc. theses in the Department of Pilot Nanobiotechnology at the Pasteur Institute of Iran, Tehran that hereby thanks to all colleagues for their invaluable help.

\section{References}

Allwood M, Stanley A,Wright, P (2002). The Cytotoxics Handbook, 4th, (UK: Radcliffe Medical Press Inc). Cubells MP, Aixela JP, Brumos VG, Pou SD, Flaque MV (1993). 
Stability of cisplatin in sodium chloride $0.9 \%$ intravenous solution related to the container's material. Pharm World Sci, 15, 34-6.

Ebrahimi Shahmabadi H, Movahedi F, Koohi Moftakhari Esfahani M, et al (2014). Efficacy of Cisplatin-loaded polybutyl cyanoacrylate nanoparticles on the glioblastoma. Tumour Biol, 35, 4799-806.

Ferdosian M, Khatami MR, Malekshahi ZV, et al (2015). Identification of immunotopes against Mycobacterium leprae as immune targets using PhDTm-12mer phage display peptide library. Trop J Pharm Res, 14, 1153-9.

Florea AM, Büsselberg D (2011). Cisplatin as an anti-tumor drug: cellular mechanisms of activity, drug resistance and induced side effects. Cancers, 3, 1351-71.

Haddad Kashani H, Fahimi H, Dasteh Goli Y, Moniri R (2017). A novel chimeric endolysin with antibacterial activity against methicillin-resistant Staphylococcus aureus. Front Cell Infect Microbiol, 30, 290.

Hosseini ES, Moniri R, Goli YD, Kashani HH (2016).Purification of antibacterial CHAP K protein using a self-cleaving fusion tag and its activity against methicillin-resistant Staphylococcus aureus. Probiotics Antimicrob Proteins, 8, 202-10.

Hrubisko M, Mc Gown AT, Prendiville JA, et al (1992). Suitability of cisplatin solutions for 14-day continuous infusion by ambulatory pump. Cancer Chemother Pharmacol, 29, 252-5.

Haddad Kashani H, Moniri R (2015), Expression of recombinant pET22b-LysK-cysteine/histidine-dependent amidohydrolase/peptidase bacteriophage therapeutic protein in Escherichia coli BL21 (DE3). Osong Public Health Res Perspect, 6, 256-60.

Haddad Kashani H, Nikzad H, Mobaseri S, Seyed Hoseini E (2012). Synergism effect of nisin peptide in reducing chemical preservatives in food industry. Life Sci J, 9.

Haddad Kashani H, Schmelcher M, Sabzalipoor H, Seyed Hosseini E, Moniri R (2018). Recombinant endolysins as potential therapeutics against antibiotic-resistant Staphylococcus aureus: Current status of research and novel delivery strategies. Clin Microbiol Rev, 31, e00071-17.

Jalali HK, Salamatzadeh A, Jalali AK, et al (2016). Antagonistic activity of Nocardia brasiliensis PTCC 1422 against isolated Enterobacteriaceae from urinary tract infections. Probiotics Antimicrob Proteins, 8, 41-5.

Lee HY, Mohammed KA, Goldberg EP, Kaye F, Nasreen N (2015). Cisplatin loaded albumin mesospheres for lung cancer treatment. Am J Cancer Res, 5, 603-15.

Lotfi A, Shiasi K, Amini R, et al (2016). Comparing the effects of two feeding methods on metabolic bone disease in newborns with very low birth weights. Glob J Health Sci, 8, 249.

Mandell G, Bennett J, Doli R (2009), Mandell, Douglas and Bennett's principles and practice of infectious diseases, 7 th Edition. eBook ISBN: 9781455708727.

Mittner A, Vincze Z, Jemnitz K (1998), Stability of cisplatin containing infusions. Pharmazie, 53, 490-2.

Panesso MC, Shi M, Cho HJ, et al (2014). Klotho has dual protective effects on cisplatin-induced acute kidney injury. Kidney Int, 85, 855-70.

Panghal M, Kaushal V, Yadav JP (2011). In vitro antimicrobial activity of ten medicinal plants against clinical isolates of oral cancer cases. Ann Clin Microbiol Antimicrob, 10, 1-11.

Piroozmand A, Haddad Kashani H, Zamani B (2017), Correlation between Epstein-Barr virus infection and disease activity of systemic lupus erythematosus: a cross-sectional study. Asian Pac J Cancer Prev, 18, 523.

Pitout JD (2012). Extraintestinal pathogenic Escherichia coli: a combination of virulence with antibiotic resistance. Front
Microbiol, 19, 9.

Rochard E, Barthes D, Courtois P (1992). Stability of cisplatin in ethylene vinylacetate portable infusion-pump reservoirs. $J$ Clin Pharm Ther, 17, 315-8.

Sanganeria P, Sachar Sh, Chandra S, et al. (2015). Cellular internalization and detailed toxicity analysis of proteinimmobilized iron oxide nanoparticles. J Biomed Mater Res B Appl Biomater, 103, 125-34.

Sewell GJ (2010). Physical and chemical stability of cisplatin infusions in PVC containers. Eur J Oncol Pharm, 4, 11-3.

Shah N, Dizon DS (2009). New-generation platinum agents for solid tumors. Future Oncol, 5, 33-42.

Singh N, SharmaAK, Magotra R, et al (2015). Histomorphological effects of cisplatin on kidney of male wistar albino rats. $J$ Evolution Med and Dent Sci, 4, 8526-31.

Singleton P (2004). Bacteria in biology, biotechnology and medicine (John Wiley and Sons). ISBN: 978-0-470-09027-5.

Song W, Tang Z, Li M, et al (2014). Polypeptide-based combination of paclitaxel and cisplatin for enhanced chemotherapy efficacy and reduced side-effects. Acta Biomater, 10, 1392-402.

Stenutz R1, Weintraub A, Widmalm G (2006). The structures of Escherichia coli O-polysaccharide antigens. FEMS Microbiol Rev, 30, 382-403.

Tsang RY, Al-Fayea T, Au HJ (2009). Cisplatin overdose: toxicities and management. Drug Saf, 32, 1109-22.

Zieske PA, Koberda M, Hines JL, et al (1991). Characterization of cisplatin degradation as affected by $\mathrm{pH}$ and light. $\mathrm{Am} J$ Hosp Pharm, 48, 1500-6.

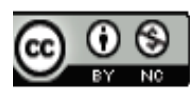

This work is licensed under a Creative Commons AttributionNon Commercial 4.0 International License. 